УДК 58(092)

doi: 10.31140/j.vestnikib.2020.3-4(214).6

\title{
НАТАЛЬЯ ИВАНОВНА НЕПОМИЛУЕВА. К 90-ЛетИю СО ДНЯ РОЖДЕНИЯ (1930-1992 гг.)
}

\author{
л.я. Огродовая \\ Институт биологии Коми научного центра Уральского отделения Российской академии наук, Сыктывкар \\ E-mail: ogrodovaya@ib.komisc.ru
}

\begin{abstract}
Аннотация. В 2020 г. исполнилось 90 лет со дня рождения Натальи Ивановны Непомилуевой - талантливого ученого-геоботаника, кандидата биологических наук, бескорыстного пытливого ученого, посвятившего всю свою жизнь проблеме охраны растительного мира Севера, подготовке материалов и обоснованию необходимости организации на территории Республики Коми генетических резерватов для сохранения редких видов и эталонов таежной растительности.
\end{abstract}

Ключевые слова: Наталья Ивановна Непомилуева, сохранение кедра сибирского (Pinus sibirica), Pecпублика Коми

31 июля 2020 г. исполнилось 90 лет со дня рождения Натальи Ивановны Непомилуевой. Талантливый ботаникгеограф, высококвалифицированный специалист, она стояла у истоков формирования системы особо охраняемых природных территорий Республики Коми, заложив основы для сохранения хрупкой северной природы нашего края, которую она искренне любила.

Особой заботой Наталии Ивановны являлся кедр сибирский (Pinus sibiri$c a)$, этот лесной великан, который на

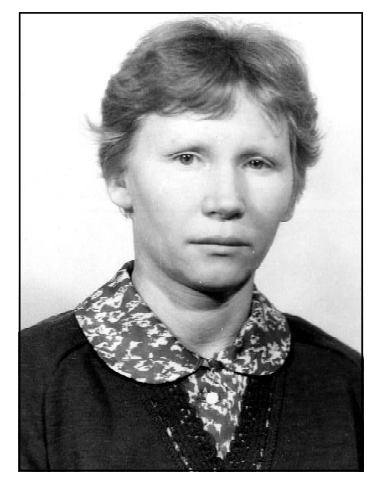

Наталья Ивановна Непомилуева

щенной ею кандидатской диссертации на тему «Эколого-географическая и фитоценотическая характеристика кедра сибирского (Pinus sibiria Du Tour) в Коми АCCP».

С 1964 г. до последних дней своей жизни Н.И. Непомилуева работала в Институте биологии, и ее внимание всегда было обращено к изучению и охране местообитаний редких растений и растительных сообществ. Она была прекрасным лектором, активно пропагандировала необходимость охраны природы, выступая перед учитерритории нашей республики находится на северо-западном пределе распространения. Ко второй половине прошлого столетия стало понятно, что необходимы срочные меры для сохранения этой древесной породы, поскольку лесные пожары, хищническая заготовка кедровых шишек, рубки угрожали ей полным уничтожением.

В процессе исследований Наталья Ивановна собрала обширный и уникальный фактический материал по экологии кедра. На основании результатов собственных многолетних полевых исследований ею была составлена детальная карта ареала кедра и по ее инициативе многие места обитания Pinus sibirica, значительно удаленные от границ сплошного распространения, были объявлены заказниками и памятниками природы. Bce предложенные к охране объекты Наталья Ивановна детально обследовала с геоботанической и таксационной точек зрения, на многих из них она проводила многолетний мониторинг. Опираясь на оригинальные данные о плодоношении кедра и его возобновлении на лесосеках, она сформировала ряд практических рекомендаций, направленных на сохранение численности вида.

Итоги многолетних исследований кедра Н.И. Непомилуева обобщила в монографической сводке «Кедр сибирский на европейском северо-востоке СCCP», его изучение легло в основу защителями, студентами, жителями республики. По рекомендациям Н.И. Непомилуевой и ее коллеги А.Н. Лащенковой были организованы более 40 заказников и памятников природы различного профиля. Немалая доля ее трудов вложена и в организацию крупнейшего резервата - национального парка «Югыд ва», природа которого уникальна.

К сожалению, Наталье Ивановне не удалось осуществить все свои творческие планы. Осталась лежать на рабочем столе рукопись монографии «Кадастр охраняемых природных территорий Республики Коми», редакцию разделов которой она не успела завершить полностью. Уже после ее смерти была опубликована монография «Таежные эталоны европейского Северо-Востока», обобщающая данные многолетних исследований по созданию охраняемых таежных эталонов и генетических резерватов основных лесообразующих пород Севера.

Но самый важный результат ее активной деятельности - сохраненные уголки девственной природы Севера. Эта работа продолжается и развивается ее последователями и коллегами и сегодня и является живой памятью о неутомимой труженице и светлом человеке - Наталье Ивановне Непомилуевой. 


\title{
NATALIA IVANOVNA NEPOMILUEVA. TO THE 90TH ANNIVERSARY \\ (1930-1992)
}

\author{
L.Ya. Ogrodovaya \\ Institute of Biology of Komi Science Center of the Ural Branch of the Russian Academy of Science, Syktyvkar
}

Summary. 2020 marks the 90th anniversary of the birth of Natalya Ivanovna Nepomilueva - a talented scientist, who devoted her whole life to the problem of protecting the flora of the North, preparing materials and justifying the need to organize genetic reserves on the territory of the Komi Republic to preserve rare species and background taiga vegetation.

Key words: Natalya Ivanovna Nepomilueva, Siberian pine (Pinus sibirica) preservation, Komi Republic

УДК 58(092)

doi: 10.31140/j.vestnikib.2020.3-4(214).7

\section{ЛАРИСА ДМИТРИЕВНА МАТЕРИЙ. К 80-ЛеТИю СО ДНЯ РОЖДЕНИЯ (1940-2000 гг.)}

\author{
O.В. Ермакова \\ Институт биологии Коми научного центра Уральского отделения Российской академии наук, Сыктывкар \\ E-mail: ermakova@ib.komisc.ru
}

\begin{abstract}
Аннотация. В 2020 г. исполнилось 80 лет со дня рождения Ларисы Дмитриевны Материй - замечательного гистолога, посвятившего себя проблемам радиочувствительности крови и кроветворных органов у животных в природной среде на радиоактивно загрязненных территориях.
\end{abstract}

Ключевые слова: Лариса Дмитриевна Материй, гистология, Республика Коми

11 ноября 2020 г. исполнилось 80 лет со дня рождения Ларисы Дмитриевны Материй - известного специалиста-радиобиолога, ученого в области гематологии, интереснейшего человека с особым научным мышлением. Ее трудовая деятельность была тесно связана с отделом радиоэкологии Института биологии, где она начала работать сразу после окончания Коми государственного педагогического института. Научные интересы Ларисы Дмитриевны были связаны с проблемой радиочувствительности

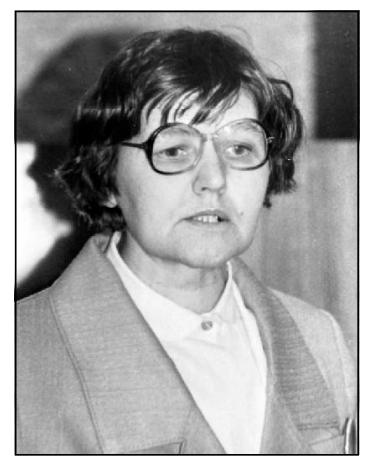

Лариса Дмитриевна Материй активности кроветворной ткани, отметила напряженный характер гемопоэза как реакции приспособления организма к хроническому действию повышенных уровней естественного радиационного фона. Результаты ее работ показали, что количественные и качественные сдвиги в системе крови полевок обусловлены, с одной стороны, повреждающим действием радиации, с другой - компенсаторно-восстановительными процессами гемопоэза. Лариса Дмитриевна доказала, что повышенный уровень природной ракрови и кроветворных органов у животных в природной среде на радиоактивно загрязненных территориях. Исследования Л.Д. Материй выявили ряд существенных закономерностей, которые легли в основу ее кандидатской диссертации. Она показала, что именно животные являются наиболее чувствительным звеном, а изменения в состоянии их системы крови дают представления о сходных процессах у человека при воздействии неблагоприятных факторов повышенной радиоактивности. Защита диссертации состоялась в Институте биологической физики АН СССР в 1979 г. и вызвала широкую дискуссию среди ученых, поскольку Л.Д. Материй подняла пласт науки, в то время мало изученный, но очень важный в плане экологической профилактики загрязненных территорий и защиты от радиации. Она обнаружила процессы усиления пролиферирующей диоактивности может вызывать соматические мутации в клетках крови млекопитающих. Ее научная гипотеза об усилении пролиферации при воздействии малых доз радиации получила свое продолжение в работах ее соратников уже на других клетках и тканях.

Когда произошла Чернобыльская катастрофа, Лариса Дмитриевна вместе со всеми сотрудниками отдела радиоэкологии активно включилась в работу по ликвидации последствий аварии, неоднократно выезжала в экспедиции в 30-километровую зону аварии на ЧАЭС. За этот самоотверженный труд она награждена почетным знаком «Ликвидатор аварии» и медалью «За спасение погибавших».

На протяжении многих лет Лариса Дмитриевна возглавляла группу гистологов в отделе радиоэкологии, создала и поддерживала атмосфе- 